\title{
EFFECT OF GLUTAMATE-ASPARTATE REPERFUSION ON POSTISCHEMIC NEONATAL MYOCARDIUM
}

\author{
S. S. Sett, MD, FRCS(C) \\ H. Tearle, RLAT \\ J. G. LeBlanc, MD, FRCS(C)
}

\begin{abstract}
Objective: We postulated that L-glutamate- and L-aspartate-enriched perfusate would improve functional recovery of postischemic neonatal rabbit hearts. Methods: Isolated working neonatal rabbit hearts were perfused with Krebs-Henseleit buffer and then subjected to 1 hour of hypothermic cardioplegic arrest with St. Thomas' Hospital solution. Hearts were then reperfused with L-glutamate- and L-aspartate-enriched $(20 \mathrm{mmol} / \mathrm{L})$ Krebs-Henseleit buffer (AA-enriched Krebs-Henseleit buffer). Hearts reperfused with Krebs-Henseleit buffer alone acted as controls (experiment A). Another group of hearts underwent a similar protocol but were reperfused with the AA-enriched Krebs-Henseleit buffer with correction of the sodium content (experiment B). Results: Hearts reperfused with AAenriched Krebs-Henseleit buffer showed a significant decrease in aortic flow at both $15(p=0.04)$ and $30(p=0.025)$ minutes compared with controls. Arrhythmias were frequent. Sodium content of the AA-enriched KrebsHenseleit buffer was $174 \pm 0.5 \mathrm{mmol} / \mathrm{L}$. In experiment $\mathrm{B}$, hearts reperfused with the AA-enriched Krebs-Henseleit buffer with correction of the sodium content exhibited no difference in aortic flow and cardiac output at either 15 or 30 minutes ( $p=0.95$ and 0.5 and 0.48 and 0.78 , respectively) compared with controls. No arrhythmias were observed. The sodium content of the AA-enriched Krebs-Henseleit buffer was $146 \pm 0.7 \mathrm{mmol} / \mathrm{L}$. Conclusions: A beneficial effect on functional recovery of neonatal hearts reperfused with AA-enriched Krebs-Henseleit buffer was not demonstrated. (J Thorac Cardiovasc Surg 1997;113:462-6)
\end{abstract}

0 ptimization of postischemic neonatal myocardial function remains an elusive goal. Amino acid supplementation of cardioplegic solutions has been advocated to improve protection of both adult ${ }^{1-3}$ and immature myocardium ${ }^{4}$ after ischemia. However, adult results are mixed ${ }^{5}$ and experimental data

From the Division of Cardiovascular and Thoracic Surgery, the Department of Surgery, the University of British Columbia; British Columbia Research Institute for Child and Family Health, Vancouver, British Columbia, Canada.

Supported by The Telethon Clinical Investigative Initiatives, British Columbia's Children's Hospital, and the Department of Surgery, University of British Columbia, Vancouver, British Columbia, Canada.

Received for publication July 9, 1996; revisions requested August 19, 1996; revisions received Oct. 18, 1996; accepted for publication Nov. 5, 1996.

Address for reprints: S. S. Sett, MD, Cardiovascular Surgery, Rm. 3G63, British Columbia Children's Hospital, 4480 Oak St., Vancouver, British Columbia, Canada V6H 3V4.

Copyright (C) 1997 by Mosby-Year Book, Inc.

$0022-5223 / 97 \$ 5.00+0 \quad \mathbf{1 2 / 1 / 7 9 0 4 5}$ is lacking in neonatal hearts. Studies in the neonatal rabbit heart have been limited to models of hypoxia, ${ }^{6}$ which is a metabolically distinct condition from ischemia. ${ }^{7}$ No studies have examined the effects on functional recovery of postischemic neonatal working hearts reperfused with solutions enriched with amino acid substrates. Intuitively this should lead to sustained improvement in functional recovery on the basis of earlier studies. We investigated the effect of an amino acid-enriched reperfusate on functional recovery of postischemic neonatal hearts in a clinically relevant model of neonatal myocardial ischemia.

\section{Materials and methods}

Isolated working heart model. Neonatal 8- to 12-dayold rabbits were kept with their does until use. After premedication with intramuscular ketamine hydrochloride $(50 \mathrm{mg} / \mathrm{kg}$ ) followed by intraperitoneal somnotol (40 $\mathrm{mg} / \mathrm{kg}$ ) and heparin (50 units $/ \mathrm{kg}$ ), a tracheostomy was performed and the animal was connected to a Harvard rodent ventilator. Ventilation prevented hearts from becoming ischemic before excision. After a median sternotomy incision, the hearts were rapidly excised and mounted 
Table I. Preischemic control values in experiment $A$

\begin{tabular}{lcccccc}
\hline \multicolumn{1}{c}{ Group } & $n$ & $\begin{array}{c}\text { AoF } \\
(\mathrm{ml} / \mathrm{min})\end{array}$ & $\begin{array}{c}\text { CoF } \\
(\mathrm{ml} / \mathrm{min})\end{array}$ & $\begin{array}{c}\text { CO } \\
(\mathrm{ml} / \mathrm{min})\end{array}$ & $\begin{array}{c}S P \\
(\mathrm{~mm} \text { Hg) }\end{array}$ & $\begin{array}{c}H R \\
(\mathrm{beats} / \mathrm{min})\end{array}$ \\
\hline $\mathrm{G}+\mathrm{A}(20 \mathrm{mmol} / \mathrm{L})$ & 8 & $28.2 \pm 2.0$ & $13.2 \pm 1.2$ & $41.5 \pm 3.1$ & $95.4 \pm 3.6$ & $331 \pm 15$ \\
$\mathrm{~K}-\mathrm{H}$ & 8 & $24.1 \pm 1.7$ & $12.3 \pm 1.2$ & $36.3 \pm 2.8$ & $87.3 \pm 4.2$ & $319 \pm 16$ \\
$p$ Value & & 0.139 & 0.6 & 0.24 & 0.17 & 0.6 \\
\hline
\end{tabular}

Data are mean \pm standard error of the mean.

$A o F$, Aortic flow; $C o F$, coronary flow; $C O$, cardiac output; $S P$, systolic pressure; $H R$, heart rate; $G+A, \mathrm{~L}$-glutamate (20 mmol/L) $+\mathrm{L}-\mathrm{aspartate}(20 \mathrm{mmol} / \mathrm{L})$ and Krebs-Henseleit solution; $K-H$, Krebs Henseleit solution.

Table II. Percent recovery of function at 15 minutes in working mode

\begin{tabular}{lccccc}
\hline \multicolumn{1}{c}{ Group } & $\begin{array}{c}\text { AoF } \\
(\text { ml/min })\end{array}$ & $\begin{array}{c}\text { CoF } \\
(\text { ml/min })\end{array}$ & $\begin{array}{c}\text { CO } \\
(\text { ml/min })\end{array}$ & $\begin{array}{c}S P \\
(m m \text { Hg })\end{array}$ & $\begin{array}{c}H R \\
(\text { beats/min })\end{array}$ \\
\hline G+A (20 mmol/L) & $45 \pm 7$ & $71 \pm 8$ & $53 \pm 7$ & $80 \pm 7$ & $90 \pm 5$ \\
K-H & $70 \pm 9$ & $90 \pm 9$ & $76 \pm 8$ & $87 \pm 4$ & $98 \pm 5$ \\
$p$ Value & 0.04 & 0.17 & 0.045 & 0.34 & 0.42 \\
\hline
\end{tabular}

on the aortic cannula of a water-jacketed Langendorff perfusion apparatus. All animals received humane care in compliance with the guidelines of the Canadian Council on Animal Care. Hearts were then perfused at a hydrostatic pressure of $55 \mathrm{~cm} \mathrm{H}_{2} \mathrm{O}$ with Krebs-Henseleit solution maintained at $39^{\circ} \pm 1^{\circ} \mathrm{C}$. Solution composition (in millimoles per liter) was as follows: $\mathrm{NaCl} 118.0, \mathrm{KCl} 4.7$, $\mathrm{NaHCO}_{3} 25.0, \mathrm{MgSO}_{4} 1.2, \mathrm{KH}_{2} \mathrm{PO}_{4} 1.2$, glucose 11.1, and $\mathrm{CaCl}_{2}$ 2.0. The perfusion solution was bubbled with a mixture of $95 \% \mathrm{O}_{2}$ and $5 \% \mathrm{CO}_{2}$ and continuously filtered with $5 \mu \mathrm{m}$ microfilters (Gelman Sciences Inc., Ann Arbor, Mich.). During a 10-minute stabilization period, excess mediastinal tissue was removed and the left atrium was cannulated with simultaneous ligation of the pulmonary veins for conversion to the working mode as described by Neely ${ }^{8}$ and modified by Bove and Stammers. ${ }^{9}$ In this preparation the oxygenated Krebs-Henseleit fluid enters the left atrium from a reservoir located $14 \mathrm{~cm}$ above the heart. The perfusate is ejected into a compliance chamber and then against a hydrostatic pressure of $55 \mathrm{~cm} \mathrm{H}_{2} \mathrm{O}$. After 15 minutes in the working mode, aortic flow was measured with timed collections from the aortic ejection line. Coronary flow was measured by timed collections underneath the heart. Aortic effluent was recirculated and filtered continuously, whereas coronary effluent was discarded. Systolic and diastolic aortic pressures, as well as heart rate, were measured continuously with a pressure transducer connected to a strip chart recorder. Myocardial temperature was measured with a needle thermistor placed in the right ventricle. Hearts exhibiting coronaryto-aortic flow ratios greater than $60 \%$ were discarded because this ratio level could indicate ischemic injury. ${ }^{10}$ The heart was arrested with St. Thomas' Hospital cardioplegic solution containing (in millimoles per liter) $\mathrm{NaCl} 110.0, \mathrm{KCl} 16.0, \mathrm{MgCl}_{2} 15.0, \mathrm{CaCl}_{2} 1.2$, and $\mathrm{NaHCO}_{3} 10.0, \mathrm{pH} 7.8$, delivered for 3 minutes at a temperature of $10^{\circ} \mathrm{C}$ from a height of $55 \mathrm{~cm}$ by way of a sidearm of the aortic ejection line. To simulate clinical conditions, we placed the heart in a cold water bath at $10^{\circ}$ to $15^{\circ} \mathrm{C}$ for 1 hour and then retrogradely reperfused it for
10 minutes followed by 30 minutes in the working mode. Postischemic aortic and coronary fows, as well as systolic and diastolic pressures, were measured at 15 and 30 minutes and were expressed as percentage of control.

Experimental groups. Hearts were reperfused with Krebs-Henseleit solution alone or with the addition of L-glutamate and L-aspartate $(20 \mathrm{mmol} / \mathrm{L}$; Ajinomoto Co., Los Angeles, Calif.)(experiment A) or with Krebs-Henseleit solution alone or with the addition of L-glutamate and $\mathrm{L}$-aspartate $(20 \mathrm{mmol} / \mathrm{L})$ but with correction of sodium content (experiment B). The sodium content of KrebsHenseleit solution was lowered by decreasing the amount of sodium chloride used to give a final sodium content that was normal for the solution $(144 \pm 0.78 \mathrm{mmol} / \mathrm{L})$.

Statistical analysis. Data are reported as mean \pm standard error of the mean. Comparison between groups was made with the Student's $t$-test with the level of significance at $p \leq 0.05$.

\section{Results}

Preischemic control values are shown for experiment A in Table I. No significant difference was found in hemodynamic values between the control and experimental groups. In experiment $\mathrm{A}$, at the end of ischemia, the temperature of the hearts was $12.7^{\circ} \pm 0.7^{\circ} \mathrm{C}$ and $11.5^{\circ} \pm 0.7^{\circ} \mathrm{C}$ in group $\mathrm{G}+\mathrm{A}$ and $\mathrm{K}-\mathrm{H}(p=0.29)$. During reperfusion in experiment A, significantly decreased aortic flows and cardiac output were seen at 15 minutes; these values were independent of the heart rate (Table II). Aortic flows were also decreased at 30 minutes of reperfusion, and, although cardiac output was less, this result was not statistically significant (Table III). The sodium content of the L-glutamate and $\mathrm{L}$ aspartate $(20 \mathrm{mmol} / \mathrm{L})+$ Krebs-Henseleit solution without correction of sodium was $174 \pm 0.5 \mathrm{mmol} / \mathrm{L}$, with osmolarity $365 \mathrm{mOsm} / \mathrm{kg} \mathrm{H}_{2} \mathrm{O}$ and $\mathrm{pH} 7.64$ 
Table III. Percent recovery of function at 30 minutes in working mode

\begin{tabular}{lccccc}
\hline \multicolumn{1}{c}{ Group } & $\begin{array}{c}\text { AoF } \\
(\text { ml/min })\end{array}$ & $\begin{array}{c}\text { CoF } \\
(\text { mllmin })\end{array}$ & $\begin{array}{c}\text { CO } \\
(\text { ml/min })\end{array}$ & $\begin{array}{c}\text { SP } \\
(\text { mm Hg) }\end{array}$ & $\begin{array}{c}\text { HR } \\
\text { (beats/min) }\end{array}$ \\
\hline G+A $(20 \mathrm{mmol} / \mathrm{L})$ & $28 \pm 7$ & $67 \pm 10$ & $40 \pm 7$ & $71 \pm 8$ & $84 \pm 11$ \\
K-H & $56 \pm 9$ & $88 \pm 12$ & $63 \pm 9$ & $80 \pm 4$ & $93 \pm 8$ \\
$p$ Value & 0.025 & 0.20 & 0.06 & 0.30 & 0.52 \\
\hline
\end{tabular}

Abbreviations are given in Table I.

Table IV. Preischemic control values in experiment $B$

\begin{tabular}{llccccc}
\multicolumn{1}{c}{ Group } & n & $\begin{array}{c}\text { AoF } \\
(\mathrm{ml} / \mathrm{min})\end{array}$ & $\begin{array}{c}\text { CoF } \\
(\mathrm{ml} / \mathrm{min})\end{array}$ & $\begin{array}{c}\text { CO } \\
(\mathrm{ml} / \mathrm{min})\end{array}$ & $\begin{array}{c}S P \\
(\mathrm{~mm} H \mathrm{Hg})\end{array}$ & $\begin{array}{c}H R \\
(\mathrm{beats} / \mathrm{min})\end{array}$ \\
\hline $\mathrm{G}+\mathrm{A}(20 \mathrm{mmol} / \mathrm{L})^{*}$ & 9 & $25.2 \pm 1.8$ & $12.8 \pm 0.9$ & $38.1 \pm 2.5$ & $99.6 \pm 4.6$ & $330 \pm 9$ \\
$\mathrm{~K}-\mathrm{H}$ & 7 & $25.4 \pm 2.7$ & $12.3 \pm 1.1$ & $37.8 \pm 3.6$ & $96.7 \pm 5.3$ & $299 \pm 16$ \\
$p$ Value & 0.9 & 0.95 & 0.73 & 0.94 & 0.69 & 0.1 \\
\hline
\end{tabular}

Abbreviations are given in Table $\mathrm{I}$.

*Sodium corrected

when bubbled with $95 \% \mathrm{O}_{2}+5 \% \mathrm{CO}_{2}$ at $39^{\circ} \mathrm{C}$. The slightly alkaline $\mathrm{pH}$ is probably a reflection of the ability of the Krebs-Henseleit perfusate to buffer the acidosis produced by the amino acid additives. Arrhythmias were frequent and were seen in seven of eight hearts during reperfusion.

Preischemic values for experiment B are shown in Table IV with no significant differences in hemodynamic parameters noted between groups. At the end of ischemia the temperature of the hearts was $12.4^{\circ}$ $\pm 0.5^{\circ} \mathrm{C}$ and $12.5^{\circ} \pm 0.4^{\circ} \mathrm{C}$ in group $\mathrm{G}+\mathrm{A}$ and $\mathrm{K}-\mathrm{H}$ $(p=0.83)$. In experiment B hearts were reperfused with the amino acid-enriched solution as in experiment $\mathrm{A}$; however, the sodium content was corrected to $146 \pm 0.7 \mathrm{mmol} / \mathrm{L}$, the osmolarity was $291 \mathrm{mOsm} / \mathrm{kg}$ $\mathrm{H}_{2} \mathrm{O}$, and the $\mathrm{pH}$ was 7.45 . No difference was found in either aortic flow or cardiac output at 15 or 30 minutes of reperfusion (Tables V and VI). Coronary flow was significantly increased in the control group at 15 minutes of reperfusion and may have resulted from an atrial leak. No arrhythmias were observed on reperfusion.

\section{Discussion}

Experimental studies have shown that glutamateand aspartate-enriched perfusate improved functional and metabolic recovery of adult myocardium after hypoxia. ${ }^{11,12}$ Hochachka and others $^{13,14}$ showed that anaerobic glycolysis was the primary pathway for energy production in diving vertebrates and that the anaerobic catabolism of the amino acids glutamate and aspartate yielded succinate, a component of the Krebs cycle. Julia and associates ${ }^{15}$ showed in puppies that more glutamate was used and more succinate was produced after normothermic global ischemia than in a control group. They suggested that this may be one mechanism that improves the tolerance of the immature heart to ischemia. Pisarenko and his group ${ }^{16}$ have shown that when glutamic acid, $20 \mathrm{mmol} / \mathrm{L}$, was added to a cold blood cardioplegic solution in patients undergoing repair of Tetralogy of Fallot, tissue levels of glutamate and adenosine triphosphate were significantly higher than in a control group of patients undergoing the same repair; this correlated with a significant difference in cardiac index 2 hours after the operation. In a similar fashion, aspartate ${ }^{17,18}$ has been shown to improve functional recovery of adult rat myocardium when added to cardioplegic solutions.

We postulated that normothermic amino acidenriched reperfusion of postischemic isolated neonatal working hearts would enhance functional recovery on the basis of the previous studies. An ischemic period of 1 hour at temperatures between $10^{\circ}$ and $15^{\circ} \mathrm{C}$ was chosen because of its clinical relevance to neonatal cardiac surgery. However we have shown that the addition of L-glutamate, and L-aspartate, $20 \mathrm{mmol} / \mathrm{L}$, to Krebs-Henseleit solution during reperfusion of postischemic neonatal rabbit hearts is detrimental to functional recovery. Many hearts were arrhythmic in contrast to control hearts which were in sinus rhythm at reperfusion. This result may be explained by the high sodium content and osmolarity of the Krebs-Henseleit solution once the monosodium salts of the amino acids have been added to it. After correction of the sodium content and osmolarity, we found no significant difference in functional recovery between control and amino 
Table V. Percent recovery of function at 15 minutes in working mode

\begin{tabular}{lccccc}
\hline \multicolumn{1}{c}{ Group } & $\begin{array}{c}\text { AoF } \\
(\mathrm{ml} / \mathrm{min})\end{array}$ & $\begin{array}{c}\text { CoF } \\
(\mathrm{ml} / \mathrm{min})\end{array}$ & $\begin{array}{c}\text { CO } \\
(\mathrm{ml} / \mathrm{min})\end{array}$ & $\begin{array}{c}\text { SP } \\
(\mathrm{mm} \mathrm{Hg})\end{array}$ & $\begin{array}{c}\text { HR } \\
(\text { beats/min) }\end{array}$ \\
\hline G+A $(20 \mathrm{mmol} / \mathrm{L})^{*}$ & $72 \pm 11$ & $87 \pm 8$ & $77 \pm 9$ & $82 \pm 5$ & $83 \pm 7$ \\
K-H & $73 \pm 7$ & $119 \pm 8$ & $86 \pm 6$ & $87 \pm 4$ & $97 \pm 2$ \\
$p$ Value & 0.95 & 0.02 & 0.48 & 0.40 & 0.13 \\
\hline
\end{tabular}

*Sodium corrected.

Table VI. Percent recovery of function at 30 minutes in working mode

\begin{tabular}{lccccc}
\hline \multicolumn{1}{c}{ Group } & $\begin{array}{c}\text { AoF } \\
(\text { mllmin })\end{array}$ & $\begin{array}{c}\text { CoF } \\
(\text { mllmin })\end{array}$ & $\begin{array}{c}\text { CO } \\
(\text { ml/min })\end{array}$ & $\begin{array}{c}\text { SP } \\
(\text { mm Hg })\end{array}$ & $\begin{array}{c}\text { HR } \\
(\text { beats/min })\end{array}$ \\
\hline G+A $(20 \mathrm{mmol} / \mathrm{L}) *$ & $58 \pm 10$ & $87 \pm 10$ & $67 \pm 9$ & $77 \pm 4$ & $84 \pm 6$ \\
$\mathrm{~K}-\mathrm{H}$ & $47 \pm 11$ & $114 \pm 15$ & $71 \pm 6$ & $79 \pm 4$ & $97 \pm 3$ \\
$p$ Value & 0.50 & 0.12 & 0.78 & 0.79 & 0.15 \\
\hline
\end{tabular}

Abbreviations are given in Table I.

*Sodium corrected.

acid-enriched reperfusion groups. The approximately $70 \%$ recovery of aortic flow and cardiac output during reperfusion in the control group may be attributable to the calcium content of the St. Thomas' Hospital cardioplegic solution used $(1.2 \mathrm{mmol} / \mathrm{L}){ }^{19}, 20$

The disparity of our results with others may have several explanations. Previously, ${ }^{6,12}$ a model of hypoxia, a metabolically distinct condition from ischemia, was used. Hochachka and Storey ${ }^{14}$ have shown that porpoises and other divers have elevated levels of aspartate and alanine amino transferases to aid in the transition from anaerobic to aerobic metabolism. In developing sheep and guinea pig hearts, however, decreased activities of these amino acid transferases have been have shown. ${ }^{21-23}$ Galinanes and associates ${ }^{24}$ have shown the mildly improved postischemic function of perfused adult rat hearts arrested with L-aspartate-enriched (20 $\mathrm{mmol} / \mathrm{L}$ ) cardioplegic solution to be related to the sodium content of the cardioplegic solution and not necessarily to the amino acid component. They concluded that the ionic composition of amino acid-enriched cardioplegic solutions requires consideration before attributing the cardioprotective properties to the additives. Although Weldner and associates ${ }^{4}$ attributed improved functional recovery of 3- to 4-week-old rabbit hearts to enrichment of a standard blood cardioplegic solution with L-glutamate, $20 \mathrm{mmol} / \mathrm{L}$, they did not compare this with another group where the blood cardioplegic solution sodium content was increased by $20 \mathrm{mmol} / \mathrm{L}$. The decreased function of hearts exposed to monosodium glutamate and aspartate immediately after ischemia may also be explained by increased sodium-hydrogen and sodium-calcium exchange resulting in worsening postischernic reperfusion injury. ${ }^{25}$ Nakanishi ${ }^{26}$ has shown the negative inotropic effect of a solution containing $\mathrm{Na}^{+}, 200 \mathrm{mmol} / \mathrm{L}$, on maximal rate of tension rise of neonatal rabbit septa.

Potential weaknesses of this study are that it was performed with the use of crystalloid perfusates and the absence of biochemical data. Qui and Hearse ${ }^{27}$ have shown that retrograde blood perfused isolated rabbit hearts were more stable, had less coronary flow, were more responsive to cardioplegic protection, and exhibited a significantly improved recovery of left ventricular pressure after ischemia as compared with crystalloid-perfused preparations. It may be postulated that these amino acids will not be effective when added to a crystalloid cardioplegic solution at temperatures between $10^{\circ}$ and $15^{\circ} \mathrm{C}$. The results presented in this article cannot be generalized to adult hearts.

Both glutamate and aspartate are excitatory neurotransmitters and are neurotoxic at sufficiently high concentrations. ${ }^{28}$ Newborn mice exposed to systemic glutamate have experienced retinal injury, and, on reaching maturity, have been noted to have neurodegenerative lesions. ${ }^{28}$ These excitatory neurotransmitters accumulate under conditions of hypoxia and ischemia, resulting in increased cellular permeability to sodium- and calcium-mediated cell death. ${ }^{29}$ Deep hypothermia and total circulatory arrest are techniques frequently used in neonatal cardiac surgery. We postulate that the use of these amino acids during repair of neonatal congenital heart disease could contribute to a poor neurologic 
outcome in addition to the potential detrimental effect on the heart.

In summary we have shown lack of a beneficial effect on functional recovery of postischemic neonatal rabbit hearts reperfused with Krebs-Henseleit solution enriched with L-glutamate and L-aspartate with or without correction of sodium. We advise caution in the use of these amino acids as cardioplegic additives in neonatal cardiac surgery because of their potential neurotoxicity, especially in the setting of circulatory arrest.

We thank Dr. G. F. O. Tyers for his assistance with the preparation of the manuscript.

\section{REFERENCES}

1. Rosenkranz ER, Okamata F, Buckberg GD, Vinten-Johansen J, Robertson JM, Bugyi H. Safety of prolonged aortic clamping with blood cardioplegia. II. Glutamate enrichment in energy-depleted hearts. J Thorac Cardiovasc Surg 1984; 88:402-10.

2. Gharagozloo F, Melendez FJ, Hein RA, et al. The effect of amino acid L-glutamate on the extended preservation ex vivo of the heart for transplantation. Circulation 1987;76(Suppl): V65-70.

3. Lazar HL, Buckberg GD, Mangarano AM, Becker H. Myocardial energy replenishment and reversal of ischemic damage by substrate enhancement of secondary blood cardioplegia with amino acids during reperfusion. $J$ Thorac Cardiovasc Surg 1980;80:350-9.

4. Weldner PW, Myers JL, Miller CA, Arenas JD, Waldhausen JA. Improved recovery of immature myocardium with Lglutamate blood cardioplegia. Ann Thorac Surg 1993;55;102-5.

5. Crooke GA, Harris LJ, Grossi EA, et al. Role of amino acids and enhancement cardioplegia in routine myocardial protection. Experimental results. J Thorac Cardiovasc Surg 1993; 106:497-501.

6. Matsuoka S, Jarmakani IM, Young HH, Uemura S, Nakanishi $\mathrm{T}$. The effect of glutamate on hypoxic newborn rabbit heart. J Mol Cell Cardiol 1986;18:897-906.

7. Tyers GFO, Morgan HE. Isolated heart perfusion techniques for rapid screening of myocardial preservation methods. Ann Thorac Surg 1975;20:56-65.

8. Neely JR, Liebermeister H, Battersby EJ, Morgan HE. Effect of pressure development on oxygen consumption by isolated rat heart. Am J Physiol 1967;212:804-14.

9. Bove EL, Stammers AH. Recovery of left ventricular function after hypothermic global ischemia. Age related differences in the isolated working rabbit heart. $J$ Thorac Cardiovasc Surg 1985:5;91:115-22.

10. Brown PS, Holland FW, Parenteau GL, Clark RE. Magnesium ion is beneficial in hypothermic crystalloid cärdioplegia. Ann Thorac Surg 1991;51:359-67.

11. Rau HE, Shine KI, Gervis A, Douglas AM, Amos EC III. Enhanced mechanical recovery of anoxic and ischemic myocardium by amino acid perfusion. Am J Physiol 1979;236: H873-9.

12. Penney DG, Cascarano J. Anaerobic rat heart, effects of glucose and tricarboxylic acid-cycle metabolites on metabolism and physiological performance. Biochem J 1970:118:221-7.
13. Hochachka PW, Owen TG, Allen JF, Whittow GC. Multiple end products of anaerobiasis in diving vertebrates. Comp Biochem Physiol 1975;50B:17-22.

14. Hochachka PW, Storey KB. Metabolic consequences of diving in animals and man. Science 1975;187:613-21.

15. Julia PI, Kofsky ER, Buckberg GD, Young HH, Bugyi HI. Studies of myocardial protection in the immature heart. I. Enhanced tolerance of immature versus acute myocardium to global ischemia with references to metabolic differences. J Thorac Cardiovasc Surg 1990;100:879-87.

16. Pisarenko OI, Portnoy VF, Studenenva IM, Arapov AD, Korostylev AN. Glutamate-blood cardioplegia improves ATP preservation in human myocardium. Biomed Biochim Acta 1987;6:499-504.

17. Rosenkranz ER, Okamato F, Buckberg GD, Robertson JM, Vinten-Johansen J, Bugyi HI. Safety of prolonged aortic clamping with blood cardioplegia. III. Aspartate enrichment of glutamate-blood cardioplegia in energy-depleted hearts after ischemic reperfusion injury. $\mathbf{J}$ Thorac Cardiovasc Surg 1986;91:428-35.

18. Choong YS, Gavin JB. L-Aspartate improves the functional recovery of explanted hearts stored in St. Thomas' Hospital cardioplegia solution at $4^{\circ} \mathrm{C}$. J Thorac Cardiovasc Surg 1990;99:510-17.

19. Magovern JA, Pae WE, Miller CA, Waldhausen JA. The immature and the mature myocardium responses to multidose crystalloid cardioplegia. J Thorac Cardiovasc Surg 1988; 95:618-24.

20. Baker JE, Boerboom LE, Olinger GN. Cardioplegia-induced damage to ischemic immature myocardium is independent of oxygen availability. Ann Thorac Surg 1990;50:934-9.

21. Barrie SE, Harris P. Myocardial enzyme activities in guinea pigs during development. Am J Physiol 1977;233(Heart Circ Physiol 2):H707-10.

22. Edwards ED, Dhand UK, Teacock MK, Sheppard DAL. Activities of enzymes concerned with pyruvate and oxaloacetate metabolism in the heart and liver of developing sheep. Biochem Biophys Acta 1975;399:217-27.

23. Rolph T, Jones CT, Parry D. Ultrastructural and enzymatic development of fetal guinea pig heart. Am J Physiol 1982: 243(Heart Circ Physiol 12):H87-93.

24. Galinanes M, Chambers DJ, Hearse DJ. Effect of sodium aspartate on the recovery of the rat heart from long-term hypothermic storage. J Thorac Cardiovasc Surg 1992;103:521-31.

25. Tani M, Neely JR. Role of intracellular sodium in calcium overload and depressed recovery of ventricular function of reperfused ischemic rat hearts, possible involvement of sodium-hydrogen and sodium-calcium exchange. Circ Res 1989; 65:1045-56.

26. Nakanishi T, Jarmakani JM. Effect of extracellular sodium on mechanical function in the newborn rabbit. Dev Pharmacol Ther 1981;2:188-200.

27. Oui Y, Hearse DL. Comparison of ischemic vulnerability and responsiveness to cardioplegic protection in crystalloid-perfused versus blood-perfused hearts. J Thorac Cardiovasc Surg 1992;103:960-8.

28. Rothman SM, Olney JW. Glutamate and the pathophysiology of hypoxic-ischemic brain damage. Ann Neurol 1986;19:105-11.

29. Meldrum B. Protection against ischemic neuronal damage by drugs acting on excitatory neurotransmission. Cerebrovasc Brain Metabol Rev 1990;2:27-57. 